\title{
The Extended Enterprise reference framework
}

\author{
H. O'Neill ${ }^{(*)}$, P. Sackett ${ }^{(* *)}$ \\ (*) ISCTE, Av. Forças Armadas, 1600 Lisboa, Portugal, tel: +351-1- \\ 7903064, fax: +351-1-7935300, email:henrique.oneill@iscte.pt \\ ${ }^{(* *)}$ The CIM Institute, Cranfield University, MK43 OAL Bedford, UK, \\ +44-1234-754073, +44-1234-750852, sackett@cim.cran.ac.uk
}

\begin{abstract}
Technologies offer a powerful enabling mechanism for companies to increase their competitive advantage. To exploit its full business performance potential, the application of technology must be aligned with the mission, objectives and goals of the business, and be integrated with the people and the organisational elements. Changing environmental conditions demand the development of new ways to visualise and to design businesses. Reference frameworks facilitate management development of the business vision and enables alignment of vision across the organisation. This article presents a new reference paradigm for the emerging manufacturing industry vision: the Extended Enterprise. The authors detail a prescriptive framework to realise the Extended Enterprise.
\end{abstract}

Keywords

Extended Enterprise, Manufacturing Business Strategy, Enterprise Modelling

\section{INTRODUCTION}

Manufacturing business paradigms have been incrementally modified by developments such as Lean Manufacturing (O'Neill, 1994). The sustained future success of business organisations depends on their capacity to anticipate trends in the environment and create organisational forms able to exploit them. Products and services must simultaneously present high quality, high variety and be cost effectively manufactured in appropriate volumes. Innovation, 
flexibility and customer service are becoming the basis of competition. This demands a manufacturing paradigm which goes beyond Lean Manufacturing: the Extended Enterprise. Analysis of the pressures now confronting manufacturing systems has identified the significance of the Extended Enterprise model (Sackett, 1994) as a paradigm offering new performance opportunities. The authors present a framework for the systematic realisation of the Extended Enterprise. We include:

- The Extended Enterprise generic description.

- The model for organisational development.

- The application to the Extended Enterprise.

\section{THE EXTENDED ENTERPRISE}

The Extended Enterprise paradigm is shown in Figure 1, Table 1.

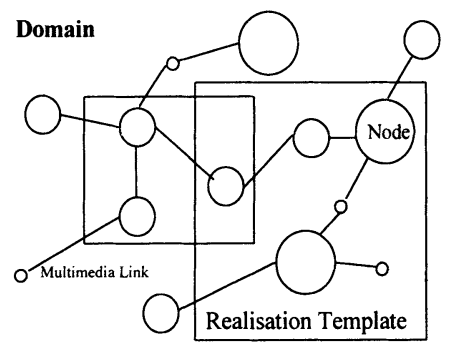

Figure 1 Extended Enterprise physical representation.

Table 1 Extended Enterprise levels

\begin{tabular}{|c|c|c|}
\hline Level & Example & Description \\
\hline Domain & The facility & $\begin{array}{l}\text { An intermeshed environment of individual small and medium sized product } \\
\text { and service business units, capable of operating as multiple overlapping } \\
\text { groups in a densely planned and controlled manufacturing business Pro } \\
\text { Service delivery system. Business Unit members may be geographically } \\
\text { remote. }\end{array}$ \\
\hline Realisation & $\begin{array}{l}\text { The } \\
\text { operational } \\
\text { Extended } \\
\text { Enterprise }\end{array}$ & $\begin{array}{l}\text { A specific Pro Service defined template applied to the Domain. Inside the Pro } \\
\text { Service template individual business unit providers fuse their business } \\
\text { processes to form a business product delivery system. This fusion is re } \\
\text { configurable and transient. }\end{array}$ \\
\hline Node & $\begin{array}{l}\text { The } \\
\text { companies }\end{array}$ & $\begin{array}{l}\text { Individual companies in the Pro Service Domain, each with functional } \\
\text { excellence or uniqueness, offering plug compatible interfaces and structured } \\
\text { transaction processing to selected members of the Domain. A Node may itself } \\
\text { comprise more than one business unit. }\end{array}$ \\
\hline
\end{tabular}

To succeed a company must reduce response time and increase quality and flexibility in their products and services. This demands the company develop its core competencies (Prahalad, 
1993) and dominate its business processes. The company must be linked to all stages of the business process, not just within its own boundaries but across the industry supply chain.

To exceed the customer's expectations requires the accurate identification of customer needs in a timely and effective way. Customer experience is a source of ideas to provide new functionality to products and services. The excellence of a company is deeply embedded in the excellence of its suppliers. The development of joint-ventures, alliances and partnerships is a core competency of the Extended Enterprise Nodes. Table 2 summarises some of the characteristics of the Extended Enterprise.

Table 2 Extended Enterprise characteristics

\begin{tabular}{ll}
\hline Customer values & $\begin{array}{l}\text { Customised product, highly flexible, easy to use and adaptable; } \\
\text { Importance of service }\end{array}$ \\
Management Philosophy & Wide Antropocentrism \\
Management Focus and Scope & $\begin{array}{l}\text { Effectiveness; Flexibility; Partnership; Facilitation; Network; Diversity; } \\
\text { Global integration } \\
\text { Investment in intra-organisational integration; Small flexible units; } \\
\text { Transnational }\end{array}$ \\
Business Strategy & $\begin{array}{l}\text { Manufacturing as a specialised form of service; Co-operative } \\
\text { manufacturing; Integration of competencies; Economies of scope }\end{array}$ \\
Manufacturing Strategy & Unitary lot size; Customised; Total product life cycle; Diversity of \\
& unique, evolving products \\
Production Type & $\begin{array}{l}\text { Participatory design; Direct Engineering; Product to use } \\
\text { Integrated customer driven planning }\end{array}$ \\
Product Development Process & Knowledge-sharing; Flexibility; Accuracy \\
Production Planning and Control & Identified with product item; Proactive \\
Supplier Dealing Base & Interactive Catalogue \\
Customers relations with product & Systemic; Cells and Teams; Widespread strategic thinking; Metaskills; \\
Trading channel & People as knowledge base \\
Organisation Structure & Multi-dimensional; Individual value \\
\hline
\end{tabular}

\subsection{The Model}

The model presented is a generic framework to support organisational design. The organisation is seen as an open system in deep interaction with its environment (Figure 2). Internal business processes transform input resources into output products and services. Feedback control mechanisms enable assessment of operational improvement (efficiency) and foster the development of new business opportunities (effectiveness).

The model details strategy in its building blocks: Mission, Objectives and Goals; Technology, Organisation and People; Actions, Communication and Co-ordination mechanisms (MOG-TOP-AC ${ }^{2}$ ). The model finds inspiration, and a theoretical background, in business oriented models: strategy (Porter, 1985), organisation (Anthony, 1965; Waterman, 1982; Beer, 1989), decision-making (Checkland, 1991) and systems analysis and design (Crossley, 1988; Heslop, 1991). The ideas are further supported by a critical analysis of examples of manufacturing best practice (Ancker, 1992; Anderson 1992; Borrus, 1993; Woodruff, 1992; McGrath, 1992, Employment Department, 1993). The model has received contributions from the discussion concerning the 'post lean manufacturing' subject (De Meyer, 1992; Karlsson, 1992). This model integrates environmental and internal characteristics, 
strategy and operations, dynamic and static structural capabilities, management style and performance measurement for decision-making support.

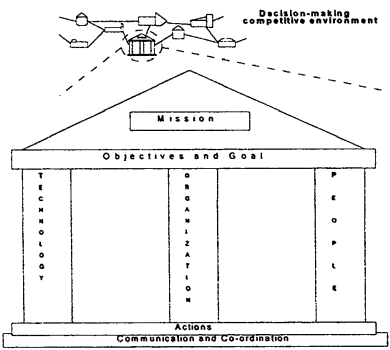

Figure 2 The organisation development MOG-TOP-AC ${ }^{2}$ model (a).

Mission describes the organisation purpose, its reason for achievement (Campbell, 1990). Objectives are linked with the long term wishes and commitments of the organisation. Goals are specific internal targets established by the enterprise to guide its progress toward fulfilling the mission. (Hanna, 1988). Technology enables the transformation processes, supports the control processes and fosters people capabilities. Organisation may be considered in its static (structure) and dynamic (transformation and control processes) components. People are the adaptive element that support the business intelligence and knowledge and develop integration capabilities. Actions that take the form of technological programmes and management initiatives, enable the organisation to foster its capabilities to interact with the environment. Continuous improvement, knowledge exploration and innovation must be the basic characteristics. Communication and co-ordination are associated with management procedures and measuring mechanisms that enable the organisation to identify changes in the environment and to assess the degree of accomplishment of objectives and goals.

\section{APPLICATION}

The Extended Enterprise is a knowledge intensive environment with the capability to distribute the formulation, implementation and control of the strategic decision-making process. Business at all levels is supported by information plus local and derived knowledge to define goals, to evaluate alternatives, to predict the need for resources, to sustain action and to monitor achievements. Flexibility is enabled by the cellular structure of the Extended Enterprise. The development of the organisation capabilities to adapt and to evolve is supported by a continuous learning process.

\subsection{Mission}

This Extended Enterprise mission statement focus is in the satisfaction of customer as the ultimate aspiration of the organisation. The purpose of the Extended Enterprise is: 
- "To provide products/services that exceed our customer's expectations, through continuous innovation, widespread strategic thinking, collaboration, decentralisation and inter-organisational integration“.

\subsection{Objectives and goals}

The Extended Enterprise objectives lead people to reinforce the organisation competitive advantages. Customer oriented long term objectives overcome financial objectives, that have a short term meaning. Customer satisfaction enables increased market share which permits exceptional financial results.

\section{Objectives}

The Extended Enterprise objectives are to:

- Build and sustain world class core competences.

- Satisfy customer's particular, hidden or implicit, needs by collaborative processes.

- Facilitate a stimulating environment that reinforces collaboration and mutual support.

- Improve suppliers' performance.

- Innovate products, production processes and services and sustain development by a continuous organisational learning process involving all stakeholders.

\section{Goals}

Until recently it has been assumed that companies competed either by providing low priced products (cost leadership), a product that is perceived as being unique (differentiation), or by serving a particular target market (focus) (Porter, 1980). Modern manufacturing competition is simultaneously set in several dimensions: cost, quality, innovation, responsiveness and service. Social responsibility is also increasingly becoming a decision factor; it can be considered both as a competitive constraint or an opportunity. An Extended Enterprise Node competes in all these dimensions simultaneously. Its focus is in the customer and not in the product. Some of the goals may be:

- To develop close relationships with customers to identify their needs.

- To improve technical, analytical, social and creative skills in all staff.

- To promote effective decentralised decision-making and team based practices.

- To share knowledge with suppliers whilst strengthing core competencies.

- To eliminate waste in the product and in the production process.

- To evaluate organisation performance against the best practitioners world wide.

- To sustain innovation by seeking continuously for new operating practices and new applications of current knowledge to create new business opportunities.

\subsection{Technology, Organisation and People}

The structural elements - Technology, Organisation and People - are configured to support the Extended Enterprise goals. 


\section{Technology}

The introduction of technologies does not always achieve the expected results (King, 1992). There may exist a mismatch between the technology, the organisation characteristics and the people capabilities that prevents the development of a more powerful whole. In Table 3 some techniques and technologies that can improve organisation performance are presented.

Table 3 Manufacturing Techniques and Technologies

\begin{tabular}{|c|c|c|c|}
\hline Techniques & 1- Simplification & 2- Automation & 3- Integration \\
\hline Production & $\begin{array}{l}\text { TQM, JIT, OPT, DF'x, } \\
\text { Group Technology, Value } \\
\text { Engineering, Simple tools }\end{array}$ & Fast Prototyping & $\begin{array}{l}\text { Cellular lay-out, Concurrent } \\
\text { Engineering }\end{array}$ \\
\hline Information & $\begin{array}{l}\text { Process mapping and re- } \\
\text { engineering, Simulation }\end{array}$ & $\begin{array}{l}\text { CAD, CAM, CAT, CNC, } \\
\text { FMS, AGV, Automatic } \\
\text { warehouses, Barcoding, } \\
\text { Optical scanners }\end{array}$ & $\begin{array}{l}\text { Cellular scheduling systems, } \\
\text { Integrated PP\&C systems } \\
\text { (pulled); Enterprise IS/ DSS, } \\
\text { EDI, CSCW, Client-server } \\
\text { architectures. }\end{array}$ \\
\hline
\end{tabular}

The information technology infrastructure enables the Extended Enterprise to operate dynamically. Computers and networks are integrated with applications are designed according to the key business processes characteristics (Taylor, 1991). Communication facilities access remote multimedia databases with technical and managerial information and directly interact with customers and suppliers for decision-making support (Smith, 1993). This information is meaningful; concerned with the present and near future instead of the past; supportive of internal tasks and oriented to the exterior: descriptive of the competitive external environment and the way the company is operating. Information systems provide well established decisionmaking support models and techniques. A base of knowledge comprising possible futures descriptions and best practice examples. These generic methods and models are used by decision makers in the context of specific manufacturing problem situation to generate appropriate decisions (Figure 3).

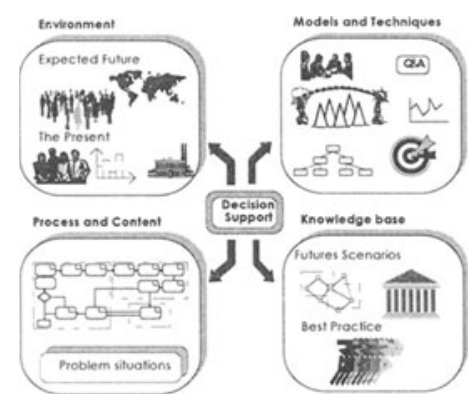

Figure 3 Information technology support to business process

Research confirms the future development of manufacturing computer-based decision support systems according to this framework (Toye, 1993). Techniques and technologies are not 
neutral entities. Their adoption impacts on the other infrastructure elements. For instance, Just-In-Time impacts the organisation at the structure (cellular lay-out) and the people (self oriented teams) levels. To achieve the full potential of technology the Extended Enterprise integrates it with the organisational structure, to expand the people's capabilities and to support a process of continuous organisational learning.

Organisation

The design of the organisational structure is determined by the distributed characteristics of the Extended Enterprise. Two basic building blocks may be considered: the Business Unit and the Extended Enterprise Supervision Unit.

\section{Business Unit}

The Extended Enterprise Nodes comprise small business units. Each Business Unit is a monitoring and control point of the Extended Enterprise network. The Business Unit has all the functionality and mechanisms that enable it to interact with its environment. It is autonomous but it is not completely independent. It has parallel mission and objectives to the Extended Enterprise to which it belongs. It co-ordinates goals and operations with the other Nodes. From the outside nothing seems to distinguish an Extended Enterprise Template from a traditional manufacturing system. The substantial difference comes in its internal structure and management practice.

Within the Business Unit two aspects may be identified: the structure (static) and the activity (dynamic). It is necessary to considers both aspects simultaneously. The design and development around the transformation process of the products and services reinforces the links between the enterprise and its environment represented by its customers and suppliers.

The Business Unit adopts a multiple cellular-process oriented structure, with cells fully responsible for each process. Each cell is managed by a team. The cell has all the means that enables it to complete its product or service. It has full capability to make decisions concerning its process. It is able to plan, run and control its activities. It can be seen as an autonomous unit within the Business Unit. Teams of (8-10) people, multiskilled, goaloriented and self-directed, working in a controlled environment, increase responsibility and individual motivation to achieve outstanding results (Handy, 1985). In a typical manufacturing business environment critical processes are: customer order fulfilment, product co-design, product co-engineering, procurement and production (Figure 4).

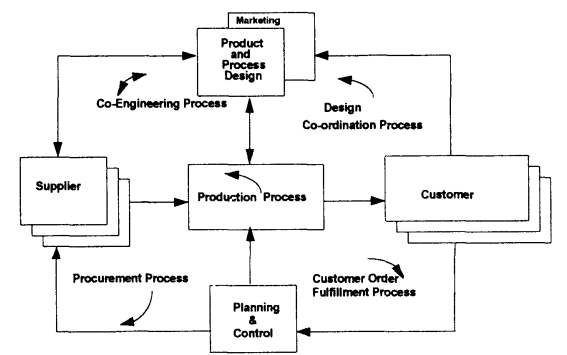

Figure 4 Manufacturing generic model (AMBITE, 1994). 
In the Extended Enterprise these processes are the result of contributions of customers and suppliers within a climate of frank co-operation. There are exciting grounds to be explored through increased collaboration and integration of operations across businesses, that is made possible by the use of modern communication systems. As a result, performance will be improved particularly in the competitive dimensions where time is critical.

The cellular-process oriented structure makes it easier to evaluate investments in technological programmes and management initiatives aimed to improve performance. It enables us to define more precise performance measurement criteria, related with quality, flexibility, responsiveness and service, to support management decision-making. (Soni, 1992). Cellular-process oriented organisation develops the positive characteristics that are associated with market structures in a hierarchical controlled environment (Busby, 1993).

\section{Supervision Unit}

When an organisation has a distributed structure, or achieves a trans-national dimension, it must be able to integrate operations to sustain and take advantage of that geographical presence. The Supervision Unit has an integration role at a global level among the several Business Units. It has authority to formalise policies concerning global objectives and goals, common technology definition, supplier management, resource optimisation and bench marking (Boyle, 1993). A Supervision Unit does not overrule Business Units. The Supervision Unit management team provides knowledge and facilitation but the ultimate responsibility belongs to the Business Unit. The Supervision Unit is an organ where representatives of the several Business Units, of customers and suppliers make decisions and detail business processes.

\section{People}

The development of the human element is the most challenging and least documented aspect in the design of any organisation. It is potentially a high return investment. Human intelligence is widespread and freely available within the organisation (Ainger, 1993). Success depends on investment to create the processes and structures able to develop its people's will, initiative, autonomy, mutual co-operation and team working skills (Dixon, 1990).

People are also the integration element in intra-organisation relations. These relations are formalised by cross-organisational business processes and inter-organisational cells, implemented by people and supported by information technology. Information and knowledge integration demands compatibility of data and processing tools. High level communication demands the full control of a common language. Facilities are developed to colocate intraorganisational cells, even in a temporary basis.

\subsection{Actions}

An action is anything an organisation does. Actions are situation dependent and company specific. Actions are the outcome of managerial decision-making. The process model of decision-making considers that most decisions and problem solving situations can be described by a sequence of steps (Newman, 1992; Kane, 1992, Harrison, 1993). The model supports a planning formulation, has a strong emphasis on action and an objective-oriented 
outcome. It may support decisions with a long-term perspective The use of the process model contributes to eliminating the negative aspects of conflict, inherent to human behaviour.

\section{The Extended Enterprise decision-making process model}

The Extended Enterprise follows a structured and systematic approach to decision making as suggested by the process model, enhanced by a creativity element and carried in an experimental basis It comprises specific activities that can be grouped in key stages: analysis, planning, implementation monitoring and control.

Improvement initiatives must be an answer to customer needs and be perceived by them. The development of a customer satisfaction assessment process is an action that the Extended Enterprise carries out. It enables the company to be in touch with customers and to consider their expectations when setting goals and actions (Zairi, 1992; Finnimore, 1993). Satisfaction assessment practices are also developed with internal customers, of support and management processes.

The process model enables us to better define objectives and goals and to detail plans of action. It facilitates the identification of areas for improvement and innovation. Process oriented organisational structure is coherent with the process model of decision-making, and mutually reinforcing strengths. Development is sustained by experimentation which is the basis of the scientific method. It fosters the Nodes to re-evaluate assumptions, to control the implementation stage and to enhance final outcomes.

\subsection{Communication and co-ordination}

\section{A practice of management}

In the Extended Enterprise, management is a widespread responsibility. Management has an internal and an external focus. Senior managers seek to develop the organisation internal capabilities to support the vision and the objectives' achievement. Vision building is a task where all people in the organisation actively participate. Everybody is qualified to identify external trends and evaluate how these trends can impact on their organisation. This increases commitment and distributes the capability of the Extended Enterprise to detect changes in its business environment. Senior management main role is to set objectives and goals and to sustain the action that make things happen. Leadership is not passive co-ordination; it is active and stimulating support. To achieve excellence leaders see themselves as part of the organisation, committed in the long-term with the Nodes fate.

\section{Measures}

Quantifiable targets have an important psychological influence on people. Results achievement foster people's will (Schaffer, 1992). To define the precise ways to assess achievement and to improve them in a continuous basis is a goal in the Nodes. In the Extended Enterprise measures are both quantitative and qualitative: indicators inferred from customer satisfaction in the key competitive dimensions of: cost, quality, flexibility, responsiveness, efficiency and co-operation. These indicators are linked with each one of the business processes. Table 4 lists some of these measures. In the Extended Enterprise, each process team is responsible by defining and selecting the measures that best fit their processes. 
To compare Business Unit performance, compatibility is kept among measures used by cells that manage similar processes. It is a senior management task to seek this compatibility.

Table 4 Extended Enterprise Measures

\begin{tabular}{|c|c|}
\hline Focus & Measures \\
\hline Cost & $\begin{array}{l}\text { Cost of products sold per unit time, Cost of task within the process, Cost of shipments per } \\
\text { unit time, Cost of outstanding orders per unit time, Average rework cost per customer return }\end{array}$ \\
\hline Quality & $\begin{array}{l}\text { Customer Quality Yield, Number of late deliveries per unit time, Average customer query } \\
\text { response time, Number of complete orders delivered on-time }\end{array}$ \\
\hline Flexibility & $\begin{array}{l}\text { Number of partnerships formed with customers per unit time, Number of order changes per } \\
\text { customer, Number of complete orders changed delivered on-time }\end{array}$ \\
\hline Responsiveness & Average customer query response time, Average time for order delivery. \\
\hline Efficiency & $\begin{array}{l}\text { Productivity of order fulfilment employees, Number of orders produced per unit time, } \\
\text { Return on value added, Sales per employee, Sales growth rate, Profit per employee }\end{array}$ \\
\hline Co-operation & $\begin{array}{l}\text { Number of partnerships made with customers/ vendors, Cross participation in previous } \\
\text { projects, Duration of vendors relationship. Number of vendors connected via EDI. }\end{array}$ \\
\hline
\end{tabular}

\section{CONCLUSIONS}

A reference framework facilitates the creation of a common vision of the future. This is particularly important in the multi partied domain of the Extended Enterprise.

To provide the customised products and services that the global market demands, companies have to reinforce flexible co-operation links among employees and with customers and suppliers. Information technologies have a fundamental role in this process. Reinventing the business must have an external, customer oriented, focus. It must be creative but meaningful. It must be implemented in a flexible but systematic way. Results must be measurable. This framework supports this. It is a basis for business process re-engineering initiatives in manufacturing. It can be used to initiate the organisation changing process towards the Extended Enterprise realisation. The Extended Enterprise reference framework must be detailed according to the organisation specific characteristics.

The approach presented in this paper forms a contribution to a joint European Commission research project being developed by academic research centres of England, Ireland and Germany, and manufacturing companies in the electronics, automotive and aircraft industries (AMBITE, 1994). The aim of this project is the specification and development of a decisionsupport system to enable a co-operative decision making process within a pan-european distributed environment concerning investments in new technology and management initiatives seeking organisational change and the introduction of Concurrent Engineering. This framework will also be explored in a research proposal that has been submited by the authors to the ESPRIT Programme.on "cooperation mechanisms and information technology infrastructure in the consumer goods manufacturing industries".

(a) MOG-TOP-AC ${ }^{2}$ is an acronym that states for Mission, Objectives and Goals; Technology, Organisation and People; Actions, Communication and Co-ordination. It can be linked with a mnemonics: MOGul (magnate, notable, celebrity, star), TOP (leader, excel) and ACademic (erudite, learned, conjectural, speculative). 


\section{REFERENCES}

Ainger, A. (1993), Human-Centred Systems Conference, The CIM Institute

AMBITE, 1994, Advanced Manufacturing Implementation Tool for Europe, Brite Euram project number 7094, Internal Report, CIM Institute, UK

Ancker, J. (1992), Thinking global and acting local (ABB Sweden), Business Process Redesign Symposium, Cranfield School of Management, UK

Anderson, R.E. (1992), Strategic Integration :How John Deere did it, Journal of business strategy, 13, 4, 21-26.

Anthony, R.N. (1965), Planning and control systems: A framework for analysis, Harvard University, Boston, MA

Borrus, M. and Cohen, S. (1993), Beyond lean: an essay, IEEE Spectrum, 30, 9, 67-69,

Boyle, E. (1993), Managing organisational networks: defining the core, Management Decision, 31, 7, $23-27$

Busby, J.S. and Fan, I.S. (1993), 'The extended manufacturing enterprise: its nature and its needs', Int. J. Technology Management, Special Issue on 'Manufacturing Technology: Diffusion, Implementation and Management', 8, 3/4/5, 294-308.

Campbell, A and Young, S. (1990), Do you need a mission statement?, The Economist Intelligence Unit, London, 1990

Checkland, P. and Scholes, J (1991), Soft systems methodology in action, John Wiley \& Sons

Crossley, T.R., Koriba, M. and Hoxar, R.A. (1988) Justification of CIM using business models based on the IDEFO methodology, Proc. 4th Int. Conf. Simulation in Manufacturing, IFS Ltd, 251-262

De Meyer A. (1992), Creating the virtual factory, INSEAD, Working papers, 92/82/TM

Dixon, J., Nanni, A. and Vollmann, T. (1990), The New performance Challenge - Measuring Operations for World-Class Competition; Business One IRWIN

Employment Department (1993), Investors in People: case studies, UK, 1993

Finnimore, P. (1993), Measuring Police Performance, Management Services, 37, 11, 12-14

Handy, C.B. (1985) Understanding Organisations, Penguin Business, 154-184

Hanna, D.P. (1988) Designing Organisations for High Performance, Addison Wesley, OD Series

Harrison, E.F. (1993) Interdisciplinary models of decision-making, Management Decision, 31, 8, 27-33

Heslop, A. (1991) Mapping and evaluation of integration in manufacturing environments, PhD Thesis, Cranfield Institute of Technology, UK

Karlsson, C. (1992) Knowledge and material flow in future industrial networks, International Journal of Production Management, 12, 7/8, 10-23

Katz, R. (1993) How a band of renegades designed the Alpha chip, Research Technology Management, 36, 6, $13-20$

Kane, E.J. (1992) Process management methodology brings uniformity to DBS, Quality Progress, 25, 6, 41-46

King, W and Ramamurthy, K. (1992) Do organisations achieve their objectives from computer-based manufacturing technologies?, IEEE Transactions on Engineering Management, 39, 2, 129-140

McGrath, M.E. and Hoole, R.W. (1992) Manufacturing's New Economies of Scale, Harvard Business Review, 70, 3, 95-102

Newman, V. (1992) The problem solving wheel, The CIM Institute, UK

O'Neill, H. and Sackett, P. (1994) The Extended Manufacturing Enterprise Paradigm, paper submitted, CIM Institute, Cranfield University, UK

Porter, M.E. (1980) Competitive Strategy, New York, Free Press, 34-46

Porter, M.E. (1985) Competitive Advantage: Creating and sustaining superior performance, New York, The Free Press

Prahalad, C.K. (1993) The role of core competencies in the corporation, Research Technology Management, 36, $6,40-47$

Sackett, P., Wortmann, H. and Brown, J. (1994) Manufacturing Business Challenges in the late 1990's. Proc. 1st SCMA Conference on Outstanding Business Success in Manufacturing, London 
Schaffer, R.H. and Thomson, H. A. (1992) Successful change programs begin with results, Harvard Business Review, 70, 1, 81-89

Smith, R.A. (1993) Information infrastructure: corporate strategic weapon or exploding cigar, Calls Journal, 2 , 4, 83-84

Soni, A. (1992) Eight steps to a JIT focused factory, Manufacturing Systems, 10, 2, 46-52

Taylor, D.L. (1991) From EDI to Inter-Enterprise Systems: A scenario for the 1990s, EDI forum, pp.19-23

Toye G., Cutkosky M. Leifer L., 1993, Share: A Methodology and Environment for Collaborative Product Development, Proceedings of the Second workshop on enabling technologies: infrastructure for collaborative enterprises, April 20-22, IEEE Computer Society Press, pp.33-47

Waterman Jr., R.H. (1982) The seven elements of strategic fit, Journal of Business Strategy, Winter, 70-71

Woodruff, D. (1992) Saturn: GM finally has a real winner, Business Week, Aug. 17, 86-91

Zairi, M. (1992) The art of benchmarking: using customer feedback to establish a performance gap, Total Quality Management, 3, 2, 122-188

\section{BIOGRAPHY}

Henrique O'Neill - PhD, MSc, Eng

Henrique O'Neill has PhD in Computer Integrated Manufacturing at the Cranfield University, and a MSc and a degree in electronic and telecommunications engineering and computer science from Instituto Superior Tecnico, Lisbon, Portugal. His professional experience includes analysis, development and implementation of information systems for industrial companies and government departments. He has been lecturer in information systems at ISCTE, a school of management in Lisbon. His teaching and research interests cover complementary areas of application of information technologies in industry: Business and manufacturing strategy, Enterprise modelling, Performance measurement, CIM architectures and Communication systems

Peter John Sackett - PhD, CEng, FIEE

Following an Engineering Apprenticeship at Rolls Royce Aero Engines, Peter Sackett worked in Aerospace Equipment, Heavy Automotive and Industry Products. His first academic appointment was at the University of Bath, UK. In 1985 he joined the Cranfield Institute to work in CIM and was involved in the IBM Trust proposal for an initiative in this area. He took up his current post in 1987 and was awarded a Personal Chair and made Professor of the University in 1990. He leads the Masters and Doctoral Programmes in CIM at Cranfield. In 1991 his team was awarded the Society of Manufacturing Engineers international prize for Leadership and Excellence in Application and Development of a CIM programme. Professor Sackett has published 70 papers in the field of manufacturing and CIM in the last decade. He has a particular interest in Design/Manufacturing Systems and International Manufacturing Enterprise Development. 